\title{
INTEGRASI JENDER DALAM PENGUATAN SOSIAL DAN EKONOMI KELUARGA NELAYAN PANCING TONDA (STUDI KASUS DI NEGERI URENG DAN NEGERI ASSILULU KECAMATAN LEIHITU KABUPATEN MALUKU TENGAH)
}

\author{
Gender Integration in The Strengthening of Social and Economic \\ Troll Line Fisheries \\ (Case Study in the Ureng Vilage and Assilulu Vilage \\ Leihitu Sub-District Central Maluku Regency)
}

\author{
Fitriyani S. Sohilauw ${ }^{*}$, D. A. J. Selanno ${ }^{2}$, dan Y. Lopulalan ${ }^{3}$ \\ ${ }^{1}$ Mahasiswa Program Studi Manajemen Sumberdaya Kelautan dan Pulau-Pulau Kecil \\ Pascasarjana Universitas Pattimura \\ ${ }^{2}$ Jurusan Manajemen Sumberdaya Perairan Fakultas Perikanan dan Ilmu Kelautan Universitas Pattimura \\ ${ }^{3}$ Jurusan Agribisinis Fakultas Perikanan dan Ilmu Kelautan Universitas Pattimura \\ fifitriydua@gmail.com
}

\begin{abstract}
ABSTRAK : Negeri Ureng dan Negeri Assilulu memiliki potensi sumberdaya perikanan yang melimpah. Jender memiliki peranan dalam memanfaatkan sumberdaya perikanan. Tujuan dari penelitian ini adalah: 1) menganalisis kondisi sosial, ekonomi dan budaya keluarga nelayan pancing tonda; 2) mengkaji persepsi keluarga nelayan pancing tonda tentang keadilan antara laki-laki dan perempuan; 3) menganalisis pembagian kerja antara laki-laki dan perempuan dalam rumah tangga nelayan pancing tonda dalam memenuhi kebutuhan hidup sehari-hari; dan 4) memformulasikan strategi integrasi jender bagi penguatan sosial dan ekonomi keluarga nelayan pancing tonda di Negeri Ureng dan Negeri Assilulu. Kondisi sosial, ekonomi dan budaya serta mengkaji menggunakan metode analisis data deskriptif kuantitatif. Analisis berbagai kegiatan laki-laki dan perempuan menggunakan metode Analyctical Hierarkhy Process (AHP). Strategi integrasi jender bagi penguatan sosial dan ekonomi keluarga nelayan pancing tonda dianalisis menggunakan metode analisis data SWOT. Berdasarkan hasil penelitian menunjukkan bahwa secara keseluruhan aktivitas kaum laki-laki adalah melaut, sedangkan kaum perempuan lebih banyak melakukan kegiatan mengurus rumah tangga. Berdasarkan pembagian kerja, kaum perempuan memiliki lebih banyak beban kerja. Terdapat 10 strategi yang dirumuskan serta 17 arahan bagi penguatan sosial dan ekonomi keluarga nelayan pancing tonda pada kedua negeri tersebut.
\end{abstract}

Kata Kunci : Nelayan, jender, integrasi, SWOT, Negeri Ureng, Negeri Assilulu

ABSTRACT: Ureng and Assilulu Village have abundant potential fisheries resources. Gender has a role in utilizing fisheries resources. The research on troll lline fisher's household was carried out at Ureng and Asslulu villages, Leihitu District, Central Maluku on December 2017 to July 2018. The objectives of this research were:1) To analyse social, economy and cultural of fishers; 2) To study the perception of fishers on equity between men and women; 3) To analyse working division between men and women to fulfill daily need, and; 4) To formulate integrated strategy to strengthening social and economy of the fisher's household. Descriptive quantitative was used to analyse social, economy and cultural of the fisher's household while Analyctical Hierarkhy Process was applied to analyse fisher's 
activities. SWOT analysis was used to formulate strategy for gender integrated in order to strengthening social and economy of the fishers. The results showed that all fishing activities were done by men while women mostly responsible for household administration and thus have more work load than men. There were 10 strategies and 17 approaches to strengthening social and economy of the troll line fisher's household at both villages.

Keywords: Fisher, gender, integrate, SWOT, Ureng Village, Assiullu Village

\section{PENDAHULUAN}

Peran semua anggota keluarga nelayan berpartisipasi memenuhi kebutuhan keluarga, baik kebutuhan harian maupun kebutuhan pendidikan atau masa depan anak. Oleh karena itu pemenuhan kebutuhan suatu keluarga nelayan tidak hanya dilakukan oleh kaum lakilaki, akan tetapi kaum perempuan juga dapat mengambil bagian menanggung kebutuhan ekonomi keluarga (Azizi, dkk., 2012; Handajani $d k k$., 2015). UNESCO (2002) mengemukakan bahwa semua manusia (baik laki-laki maupun perempuan) bebas mengembangkan kemampuan personal mereka dan membuat pilihan-pilihan tanpa dibatasi oleh stereotype (peran jender yang kaku) atau "kesetaraan jender". Hal ini bukan berarti bahwa perempuan dan laki-laki harus selalu sama, tetapi hak, tanggung jawab dan kesempatannya tidak dipengaruhi oleh jenis kelamin. Jender tidak menjadi masalah apabila dilakukan secara adil karena akan menguntungkan kedua belah pihak. Sebaliknya jender akan menjadi masalah apabila terjadi ketidakadilan atau ketimpangan dalam pemberlakuannya.

Andriati (2010) mengemukakan bahwa jumlah serta curahan waktu kaum perempuan masyarakat pesisir dalam berbagai kegiatan rumah tangga pada umumnya lebih tinggi jika dibandingkan dengan curahan waktu kerja kaum laki-laki. Kondisi ini dikarenakan pandangan sosial terhadap perempuan yang merupakan penanggungjawab pekerjaan domestik (mengatur rumah tangga), sehingga membutuhkan waktu yang lebih banyak. Pekerjaan rumah tangga dilakukan oleh kaum perempuan yaitu sebelum dan sesudah melakukan pekerjaan mencari nafkah membantu suami. Kondisi ini menunjukan adanya peran ganda kaum perempuan pesisir (sebagai ibu rumah tangga dan sebagai pencari nafkah), sehingga menyebabkan mobilitas tenaga kerja perempuan terbatas. Oleh karena perempuan harus tetap memperhatikan tugas dalam rumah tangga, walaupun bertugas membantu suami mencari nafkah. Peran kaum perempuan dalam rumah tangga nelayan penting untuk dipahami karena berkontribusi membantu meringankan pemenuhan tuntutan kebutuhan hidup seharihari rumah tangga (Hutapea, dkk., 2012; Kruijssen et al., 2018). Relasi yang dibangun antara perempuan dan laki-laki menjadi penting untuk diteliti, karena pada sebagian besar masyarakat, relasi yang seimbang antara lakilaki dan perempuan masih memperlihatkan tidak adanya kesetaraan jender seperti pembagian waktu untuk aktivitas di rumah dan aktivitas bekerja di luar rumah.

Negeri Ureng dan Negeri Assilulu memiliki potensi sumberdaya perikanan yang melimpah dan menjadi sumber mata pencahariaan utama bagi keluarga nelayan pancing tonda. Aktivitas melaut merupakan rutinitas yang dilakukan oleh kaum laki-laki, sedangkan aktivitas di wilayah daratan meliputi aktivitas di dalam rumah tangga maupun aktivitas penunjang ekonomi keluarga lainnya dilakukan oleh kaum perempuan. Keikutsertaan kaum perempuan untuk membantu kaum lakilaki (suami) dalam pemenuhan kebutuhan ekonomi keluarga menempatkan kaum perempuan pada penambahan rutinitas aktivitas harian serta curahan waktu. Peran laki-laki dan perempuan dalam keluarga pancing tonda menunjukkan adanya ketidakadilan jender dalam pemenuhan tanggung jawab, dan hal ini dianggap wajar dan menjadi konsep pemahaman kehidupan sosial dalam keluarga nelayan pancing tonda. Kondisi sosial dan budaya yang dipahami dan dianut masyarakat pada umumnya 
turut mengalami perubahan dan tidak didasarkan pada keadilan jender.

Tujuan dari penelitian ini adalah: (1) Menganalisis kondisi sosial, ekonomi dan budaya keluarga nelayan pancing tonda. (2) Mengkaji persepsi keluarga nelayan pancing tonda tentang keadilan antara laki-laki dan perempuan. (3) Menganalisis pembagian kerja antara laki-laki dan perempuan dalam rumah tangga nelayan pancing tonda dalam memenuhi kebutuhan hidup sehari-hari,

Memformulasikan strategi integrasi jender bagi penguatan sosial dan ekonomi keluarga nelayan pancing tonda di Negeri Ureng dan Negeri Assilulu.

\section{METODE PENELITIAN}

Penelitian ini dilakukan di Negeri Ureng dan Negeri Assilulu Kecamatan Leihitu Kabupaten Maluku Tengah (Gambar. 1). Penelitian ini dilaksanakan pada bulan Desember 2017-Juli 2018.

Sumber data yang akan dikumpulkan melalui metode survei (Singarimbun dan Effendi, 2008) yang terdiri dari data primer yang merupakan data dari informasi penelitian dan data sekunder diperoleh dari informasi maupun kajian kepustakaan terkait penelitian, baik itu dari lembaga pemerintah, maupun hasil- hasil penelitian. Analisis kondisi sosial, ekonomi dan budaya serta mengkaji persepsi masyarakat menggunakan metode deskriptif kuantitatif (Sugiyono, 2008). Analisis berbagai kegiatan laki-laki dan perempuan menggunakan metode analisis data Analyctical Hierarkhy Process/AHP (Saaty, 1993). Sedangkan strategi integrasi jender bagi penguatan sosial dan ekonomi keluarga nelayan pancing tonda di Negeri Ureng dan Negeri Assilulu dianalisis menggunakan metode analisis data SWOT (Rangkuti, 2001).

\section{HASIL DAN PEMBAHASAN}

\section{Jumlah Anggota Keluarga dan Perbandingan Laki-Laki Perempuan}

Berdasarkan hasil penelitian menunjukkan bahwa pada 16 keluarga nelayan di Negeri Assilulu memiliki jumlah anggota keluarga yaitu sebanyak 5 orang (ayah, ibu dan 3 orang anak). Jumlah anggota keluarga nelayan terbanyak juga ditemukan di Negeri Assilulu yaitu sebanyak 12 anggota keluarga (ayah, ibu dan 10 orang anak), dan paling sedikit yaitu 1 (satu) orang dengan statusnya belum berkeluarga. Selain itu, pada Negeri Ureng ada 12 keluarga nelayan memiliki jumlah anggota keluarga yaitu sebanyak 6 orang terdiri dari ayah, ibu dan 4 orang anak (Gambar 2).



Gambar 1. Peta Lokasi Penelitian 


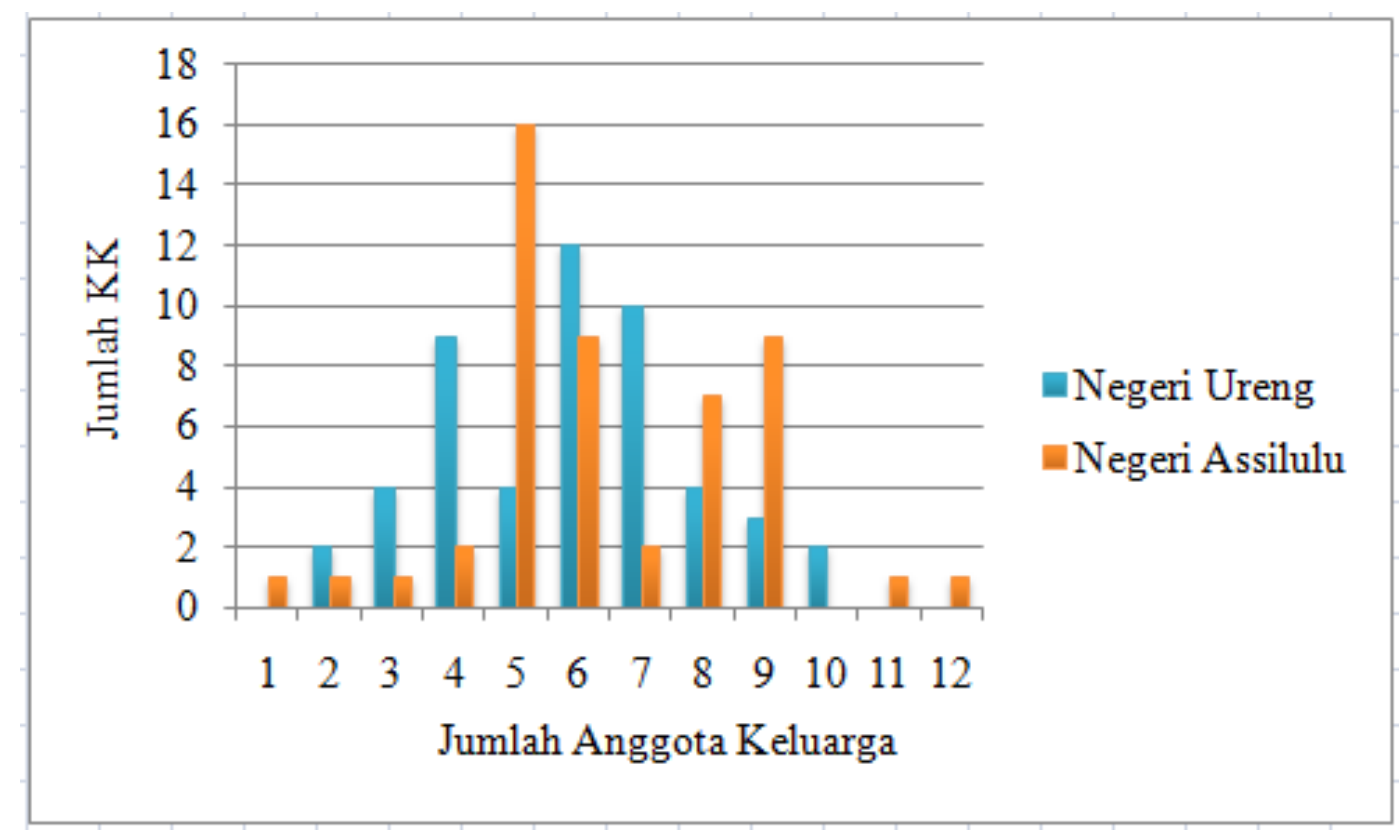

Gambar 2. Jumlah Anggota Keluarga Nelayan Pancing Tonda di Negeri Ureng dan Negeri Assilulu

Laki-laki dalam seluruh keluarga nelayan di Negeri Ureng berjumlah 154 orang atau sebesar 53\%, lebih besar dibandingkan dengan jumlah perempuan pada seluruh keluarga nelayan yang berjumlah 139 orang atau sebesar 47\% (DKP Maluku Tengah, 2015). Kondisi yang berbeda ditemukan di Negeri Assilulu, persentase perempuan dalam seluruh keluarga nelayan lebih tinggi yaitu $54 \%$ dengan jumlah 173 orang, sedangkan laki-laki berjumlah 148 orang yaitu sebesar $46 \%$.

\section{Tingkat Pendidikan}

Tingkat pendidikan suami dan isteri dalam keluarga nelayan pancing tonda bervariasi mulai dari tidak bersekolah hingga strata satu (S1). Menunjukkan kategori tingkat pendidikan terbanyak baik laki-laki (suami) dan perempuan (isteri) di Negeri Ureng dan Negeri Assilulu adalah tamatan SD. Tingkat Pendidikan nelayan laki-laki (suami) di Negeri Ureng sebanyak 25 orang adalah tamatan SD (50\%), sedangkan kaum perempuan (isteri) berjumlah 24 orang adalah tamatan SD (47.06\%). Berbeda dengan Negeri Ureng, kaum perempuan (isteri) di Negeri Assilulu sebanyak 21 orang adalah tamatan SD (43.75\%) dan laki-laki (suami) sebanyak 15 orang $(30 \%)$. Kategori tamatan strata satu (S1) baik Negeri Ureng maupun Negeri Assilulu hanya ditemukan pada kaum perempuan dengan jumlah masing-masing satu orang. Kondisi ini menunjukkan tingkat pendidikan suami dan isteri keluarga responden nelayan pancing tonda masih rendah (Watung, $d k k ., 2013)$.

\section{Tingkat Pendidikan Anak Laki-laki dan Perempuan}

Tingkat pendidikan tertinggi bagi anak laki-laki maupun perempuan dalam keluarga nelayan pancing tonda di Negeri Ureng memiliki tingkat Pendidikan tertinggi yaitu SMA. Diikuti tingkat pendidikan SMP dan Strata 1 (S1). Hal ini menunjukkan bahwa walaupun ada anak yang belum sempat menyelesaikan pendidikannya, namun orang tua tetap berusaha untuk menyekolahkan anaknya. Sebaliknya tingkat pendidikan terakhir bagi anak laki-laki dan perempuan keluarga nelayan Negeri Assilulu yang telah tamat tertinggi adalah tamat SMA baik untuk laki-laki $(60,42 \%)$ maupun perempuan $(68,18 \%)$, diikuti oleh tingkat Pendidikan SMP dan S1. Selain itu anak yang sementara menempuh pendidikan yaitu pada jenjang Pendidikan TK, SD, SMP, SMA, D3 dan S1. 


\section{Status Sosial}

Responden nelayan pancing tonda di Negeri Ureng dengan status sebagai tokoh masyarakat berjumlah 2 orang meliputi anggota dan kepala pemuda, dan yang berstatus sebagai masyarakat biasa berjumlah 48 orang. Pada Negeri Assilulu, responden nelayan pancing tonda sebanyak 2 orang merupakan perangkat negeri (Saniri Negeri atau anggota badan pemerintahan). Kategori tokoh masyarakat yaitu sebanyak 4 orang dan kategori masyarakat biasa berjumlah 44 orang. Kondisi ini memperlihatkan bahwa pada Negeri Ureng dan Assilulu nelayan juga diberi tanggung jawab sosial untuk ikut serta membangun negeri.

\section{Kondisi Ekonomi Keluarga Nelayan Pancing Tonda di Negeri Ureng dan Negeri Assilulu Pekerjaan dan Pendapatan}

a. Laki-laki atau Suami

1) Sebagai Nelayan

Nelayan pancing tonda yang ada pada Negeri Ureng dan Negeri Assilulu mengklasifikasi waktu melaut dalam dua kategori musim yaitu melaut pada musim ikan dan bukan musim ikan. Dalam satu hari nelayan dapat melakukan aktivitas melaut $\pm 11-19$ jam . Sebanyak 35 orang nelayan di Negeri Ureng dan 40 orang nelayan di Negeri Assilulu memiliki armada dan alat tangkap secara pribadi. Beberapa nelayan lainnya harus menyewa atau meminjam armada penangkapan maupun mesin perahu dari nelayan yang lain. Konsekuensi dari hal ini yaitu harus memberikan $10 \%$ dari setiap hasil tangkapan yang diperoleh, jika hasil tangkapan yang terjual minimal Rp 1,000,000. Baik kepemilikan alat tangkap maupun musim ikan atau bukan musim ikan dapat memberikan pengaruh terhadap rata-rata pendapatan nelayan tersebut (Tabel 1).

Nilai pendapatan 1 bulan yang diperoleh responden saat musim tangkap sangat berbeda dengan pendapatan responden yang diperoleh dalam 1 bulan saat bukan musim tangkap. Kisaran pendapatan untuk 1 (satu) bulan saat bukan musim tangkap dikelompokkan dalam 8 kategori dengan kisaran nilai Rp 100,000-Rp 10,000,000 (Tabel 2).

Tabel 1. Rata-rata pendapatan satu bulan melaut nelayan pancing tonda saat musim ikan

\begin{tabular}{cccc}
\hline \multirow{2}{*}{ No } & $\begin{array}{c}\text { Pendapatan dalam } 1 \\
\text { bulan }(\mathrm{Rp})\end{array}$ & Negeri Ureng & Nelayan (Orang) \\
\cline { 3 - 4 } & $1,000,000-10,000,000$ & 36 & Negeri Assilulu \\
\hline 1 & $11,000,000-20,000,000$ & 5 & 36 \\
2 & $21,000,000-30,000,000$ & 3 & 2 \\
3 & $31,000,000-40,000,000$ & 3 & 2 \\
4 & $41,000,000-50,000,000$ & 2 & - \\
5 & $51,000,000-60,000,000$ & 1 & - \\
6 & Jumlah & 50 & 50 \\
\hline
\end{tabular}

Sumber: data primer yang diolah, 2018

Tabel 2. Pendapatan satu bulan melaut nelayan pancing tonda saat bukan musim ikan

\begin{tabular}{cccc}
\hline \multirow{2}{*}{ No } & Pendapatan dalam 1 bulan & \multicolumn{2}{c}{ Nelayan (orang) } \\
\cline { 3 - 4 }$(\mathrm{Rp})$ & Negeri Ureng & Negeri Assilulu \\
\hline 1 & $100,000-1,000,000$ & 22 & 29 \\
2 & $1,100,000-2,000,000$ & 10 & 10 \\
3 & $2,100,000-3,000,000$ & 6 & 3 \\
4 & $3,100,000-4,000,000$ & 2 & 2 \\
5 & $4,100,000-5,000,000$ & 8 & 3 \\
6 & $5,100,000-6,000,000$ & 1 & 2 \\
7 & $6,000,000-7,000,000$ & - & - \\
8 & $10,000,000$ & 1 & 50 \\
\hline
\end{tabular}


Semakin jauh daerah penangkapan, semakin besar biaya yang harus dikeluarkan oleh nelayan tersebut untuk aktivitas penangkapan. Faktor perbedaan harga jual hasil tangkapan pada pengumpul juga mempengaruhi hasil pendapatan. Satu orang pengumpul dapat menentukan sendiri harga yang berbeda untuk membeli hasil tangkapan yang dijual nelayan. Kisaran harga jual 1 (satu) $\mathrm{kg}$ loin tuna untuk para pengumpul Negeri Ureng berkisar antara Rp40,000-Rp65,000/Kg, sedangkan kisaran harga jual di Negeri Assilulu berkisar antara Rp45,000-Rp77,000/Kg.

2) Pekerjaan tambahan selain sebagai nelayan

Rendahnya pendapatan melaut nelayan saat bukan musim ikan membuat nelayan harus mencari pekerjaan tambahan lainnya sebagai upaya untuk tetap memenuhi kebutuhan keluarga setiap hari. Berbagai jenis pekerjaan tambahan nelayan di Negeri Ureng dan Negeri Assilulu (Tabel 3).
Lamanya waktu yang digunakan untuk melakukan pekerjaan tambahan berkisar antara 2-13 jam per hari. Aktivitas pekerjaan tambahan ini pada umumnya dikerjakan pada pukul 06.00 WIT -17.00 WIT. Khusus untuk aktivitas berkebun, kegiatan ini biasanya dilakukan pada pukul 06.00 WIT-12.00 WIT.

\section{b. Pekerjaan dan Pendapatan Perempuan (Isteri)}

Perempuan nelayan turut berperan membantu suami untuk memenuhi kebutuhan hidup (Masitho, dkk., 2013). Hasil observasi ditemukan bahwa ada istri nelayan pancing tonda Negeri Ureng dan Negeri Assilulu yang memiliki perkerjaan sebagai wirausaha, berkebun dan papalele yaitu sebanyak 38 orang di Ureng dan 30 orang di Assilulu, dan satu orang yang berprofesi sebagai guru (Tabel 4). Rata-rata pendapatan pekerjaan istri nelayan pada kedua negeri tersebut terbesar berkisar antara Rp.150.000-Rp.500.000 per bulan (Tabel $5)$.

Tabel 3. Pekerjaan tambahan nelayan pancing tonda di Negeri Ureng dan Negeri Assilulu

\begin{tabular}{clcccl}
\hline \multirow{2}{*}{ No } & Pekerjaan & \multicolumn{2}{c}{ Nelayan (orang) } & \multirow{2}{*}{ Keterangan } \\
\cline { 3 - 4 } & Tambahan & Negeri Ureng & Negeri Assilulu & \\
\hline 1 & Petani & 40 & 22 & - & 8 orang responden di Negeri Ureng \\
2 & Ojek & 1 & - & tidak bekerja \\
3 & Buruh Bangunan & 1 & 4 & - & 21 responden di Negeri Assilulu \\
4 & Tukang Batu & - & 1 & tidak bekerja \\
5 & Nelayan Bubu & - & 1 & \\
6 & Wiraswasta & - & 1 & \\
\hline & & \multicolumn{2}{l}{ Jumlah Seluruh Responden } & 100
\end{tabular}

Sumber: data primer yang diolah, 2018

Tabel 4. Kategori pekerjaan isteri responden nelayan pancing tonda di Negeri Ureng dan Negeri Assilulu

\begin{tabular}{|c|c|c|c|c|}
\hline \multirow{2}{*}{ No } & \multirow{2}{*}{$\begin{array}{l}\text { Pekerjaan } \\
\text { Tambahan }\end{array}$} & \multicolumn{2}{|c|}{ Isteri nelayan (orang) } & \multirow{2}{*}{ Keterangan } \\
\hline & & Negeri Ureng & Negeri Assilulu & \\
\hline 1 & Wirausaha & 19 & 12 & $\begin{array}{l}\text { - } 12 \text { orang isteri nelayan di Negeri } \\
\text { Ureng tidak bekerja }\end{array}$ \\
\hline 2 & Berkebun (petani) & 9 & 11 & $\begin{array}{l}1 \text { orang isteri nelayan di Negeri } \\
\text { Ureng berprofesi sebagai guru }\end{array}$ \\
\hline 3 & Papalele & 10 & 7 & $\begin{array}{l}\text { - } \quad 18 \text { orang isteri nelayan di Negeri } \\
\text { Assilulu tidak bekerja }\end{array}$ \\
\hline & Total & 38 & 30 & \\
\hline
\end{tabular}


Tabel 5. Kategori rata-rata pendapatan dari pekerjaan istri nelayan pancing tonda di Negeri Ureng dan Negeri Assilulu

\begin{tabular}{clcc}
\hline \multirow{2}{*}{ No } & \multirow{2}{*}{ Pendapatan Pekerjaan per Bulan (Rp) } & \multicolumn{2}{c}{ Isteri nelayan (orang) } \\
\cline { 3 - 4 } & & Negeri Ureng & Negeri Assilulu \\
\hline 1 & $\leq 100,000$ & 4 & 3 \\
2 & $150,000-500,000$ & 12 & 9 \\
3 & $550,000-1,000,0000$ & 5 & 2 \\
4 & $1,100,000-5,000,000$ & 8 & 7 \\
5 & $>5,000,000$ & 1 & 1 \\
\hline & & 30 & 22 \\
\hline
\end{tabular}

Sumber: data primer yang diolah, 2018

\section{Analisis Peran}

\section{Aktivitas Harian}

Peran kaum laki-laki dan perempuan dalam keluarga nelayan pancing tonda meliputi suami selaku kepala keluarga, isteri dan anakanak. Keluarga responden nelayan pancing tonda yang ada di Negeri Ureng dan Negeri Assilulu dengan anggota keluarga yang berfariasi jumlah laki-laki dan perempuannya memiliki kemiripan dalam berbagai aktivitas kesehariannya. Perbedaan yang terlihat adalah dari aktivitas harian suami yang sebagian besar waktunya dihabiskan untuk melaut dan isteri dengan berbagai aktivitas yang dikerjakannya dalam satu hari. Aktivitas harian suami dalam rumah tangga nelayan pancing tonda ditampilkan dalam Gambar. 3.

Aktivitas suami dalam keluarga nelayan pancing tonda, berbeda dengan aktivitas harian isteri dalam rumah tangga nelayan pancing tonda yang ada di Negeri Ureng dan Negeri Assilulu. Beberapa aktivitas para isteri pada kedua negeri yang ditemukan memiliki persamaan serta ditemukan perbedaan aktivitas yang dijalankan setiap harinya. Aktivitas harian isteri nelayan pancing tonda dapat dilihat pada Gambar 4 dan 5.

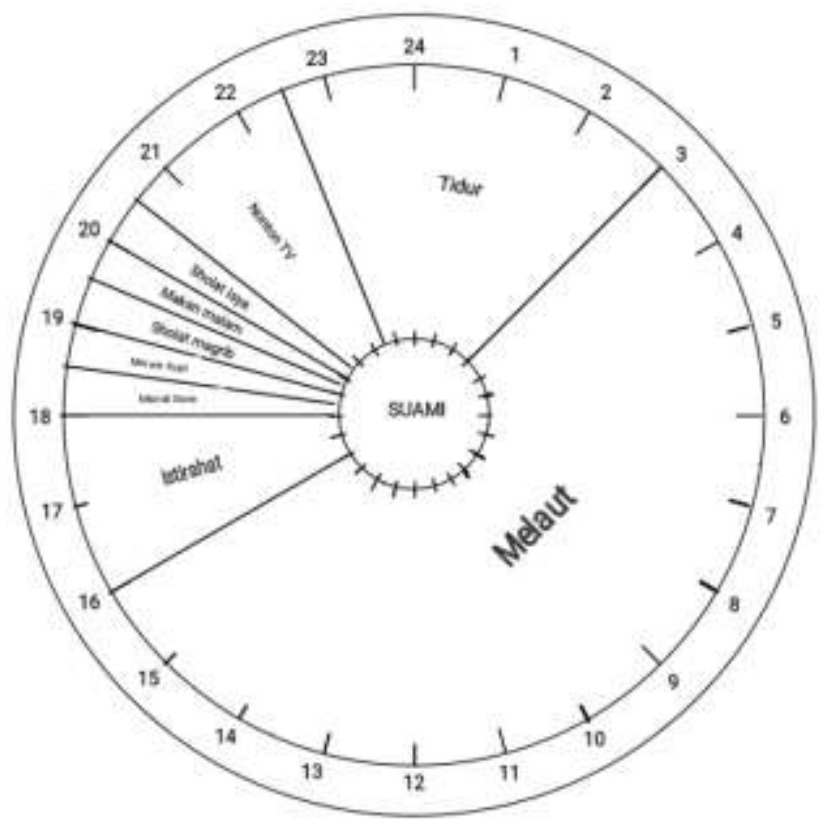

Gambar 3. Aktivitas harian responden (suami) 


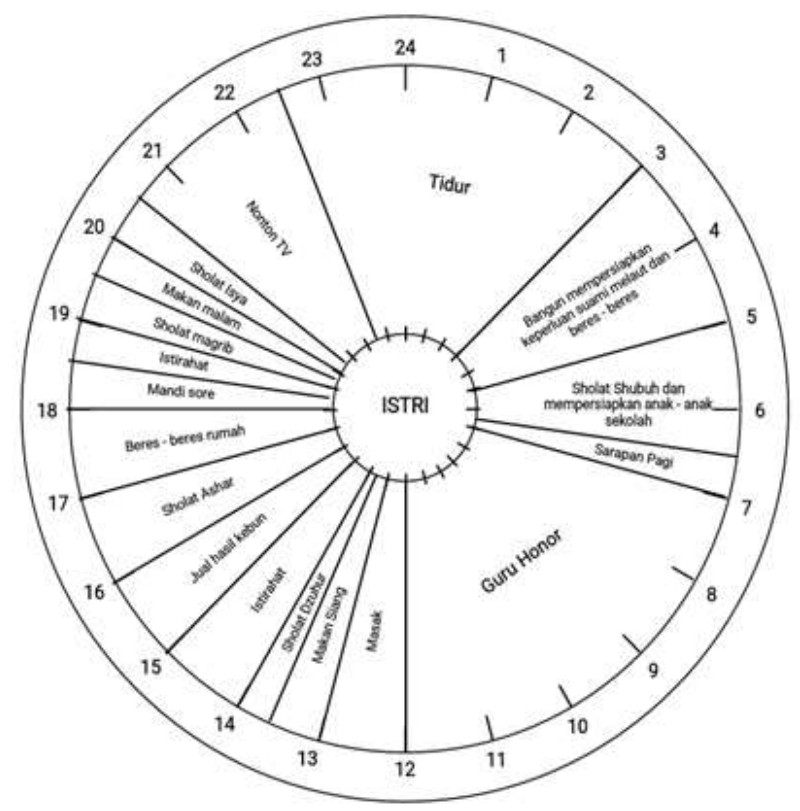

Gambar 4. Aktivitas harian isteri responden di Negeri Ureng (responden nomor 11)

Jumlah aktivitas isteri responden di Negeri Ureng tercatat memiliki 18 aktivitas dan isteri responden di Negeri Assilulu memiliki 15 aktivitas, sedangkan rata-rata untuk suami memiliki 9 aktivitas yang dikerjakan dalam kurun waktu 24 jam. Keseharian suami terfokus pada aktivitas melaut dengan harapan dapat mengoptimalkan aktivitas melautnya untuk memperoleh hasil tangkapan sebanyakbanyaknya.

\section{Tingkat Pengambilan Keputusan dalam Keluarga}

Berdasarkan hasil penelitian, hampir sebagain besar pengambilan keputusan dalam rumah tangga nelayan pancing tonda didominasi oleh perempuan (istri). Berbagai keputusan penting yang turut melibatkan peran isteri meliputi pendidikan anak, kesehatan keluarga, pemenuhan kebutuan ekonomi sehari-hari, hingga penjualan hasil tangkapan suami (Kusumo, dkk., 2013). Lamanya waktu yang digunakan untuk aktivitas melaut mengakibatkan terkadang dilimpahkannya beberapa persoalan rumah tangga kepada isteri dan dipercayakan untuk dapat mengambil keputusan dengan mempertimbangkan kondisi rumah tangga saat ini.

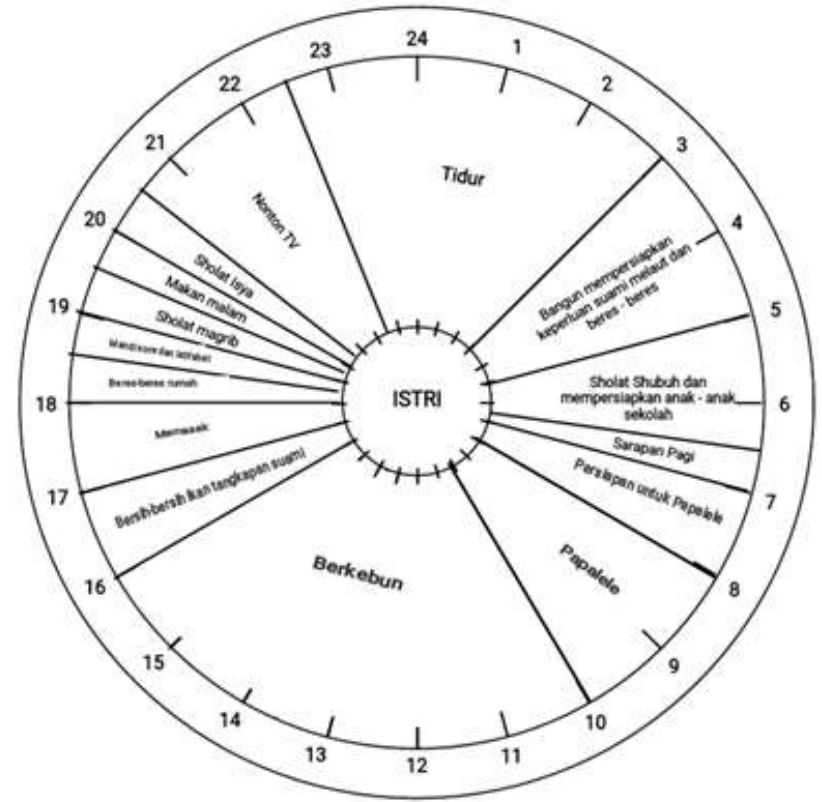

Gambar 5. Aktivitas harian isteri responden di Negeri Assilulu (responden nomor 5)

\section{Pembagian Kerja antara Laki-laki dan Perempuan dalam Rumah Tangga Nelayan Pancing Tonda di Negeri Ureng dan Negeri Assilulu}

Kaum laki-laki dan perempuan dalam rumah tangga responden nelayan pancing tonda yang ada di Negeri Ureng dan Negeri Assilulu memiliki kemiripan rata-rata jumlah waktu kerja yaitu 15 jam, 45 menit untuk perempuan dan 11-19 jam untuk kaum laki-laki. Jenis aktivitas keseharian antara lain memasak, mencuci pakaian, menyeterika, mencuci pakaian, membersihkan rumah dan halaman, mengurus suami dan anak, belanja keperluan sehari-hari, melaut, mengajar, dan berwirausaha. Kaum laki-laki dan kaum perempuan dalam keluarga nelayan pancing tonda di Negeri Ureng dan Negeri Assilulu, kesehariannya mengerjakan berbagai pekerjaan yang pembagian pekerjaan tersebut didasarkan pada jender maupun kebiasaan pola hidup masyarakat pesisir yang sudah dianggap wajar.

\section{Strategi Integrasi Jender Bagi Penguatan Sosial dan Ekonomi Rumah Tangga Nelayan Pancing Tonda.}

Penentuan strategi-strategi di bidang sosial dan ekonomi rumah tangga nelayan pancing tonda perlu dilandaskan pada 
pemahaman terhadap adanya faktor internal dan eksternal yang dirumuskan dalam upaya menganalisis dan menentukan strategi integrasi jender bagi penguatan sosial dan ekonomi drumah tangga nelayan pancing tonda. Aspek- aspek tersebut meliputi kekuatan (S), peluang (O), kelemahan (W) dan ancaman (T), yang dimiliki oleh kaum laki-laki dan perempuan sehingga kita dapat menentukan strategi yang sesuai dan berdasarkan kebutuhan (Tabel 6).

Tabel 6. Hasil analisis SWOT dan TOWS

\begin{tabular}{|c|c|c|}
\hline Kekuatan (S) & Peluang (O) & Strategi (SO) \\
\hline $\begin{array}{l}\text { 1.Ada potensi sumberdaya pesisir dan } \\
\text { laut } \\
\text { 2.Ada sumberdaya manusia } \\
\text { 3.Pengetahuan tentang sumberdaya } \\
\text { perikanan yang berekonomis tinggi } \\
\text { 4.Mampu mengatur keuangan } \\
\text { keluarga }\end{array}$ & $\begin{array}{l}\text { 1.Terbukanya akses penjualan } \\
\text { hasil tangkapan } \\
\text { 2.Adanya kesempatan untuk } \\
\text { mengembangkan diri } \\
\text { 3.Peningkatan pendapatan } \\
\text { keluarga }\end{array}$ & $\begin{array}{l}\text { 1.Penguatan sumberdaya manusia } \\
\text { dalam pemanfaatan dan pengelolaan } \\
\text { sumberdaya perikanan }\end{array}$ \\
\hline Kelemahan (W) & Peluang (O) & Strategi (WO) \\
\hline $\begin{array}{l}\text { 1. Ketidakstabilan harga jual hasil } \\
\text { tangkapan } \\
\text { 2. Hubungan sosial mempengaruhi } \\
\text { nilai jual hasil tangkapan } \\
\text { 3. Belum tersedianya peraturan tertulis } \\
\text { tentang aktivitas perikanan } \\
\text { dikawasan negeri } \\
\text { 4.Tidak bertahannya organisasi atau } \\
\text { kelompok nelayan } \\
\text { 5.Potensi sumberdaya alam } \\
\text { dimanfaatkan secara bebas }\end{array}$ & $\begin{array}{l}\text { 1. Adanya kesempatan untuk } \\
\text { mengembangkan diri } \\
\text { 2.Peningkatan pendapatan } \\
\text { keluarga } \\
\text { 3. Terbukanya akses penjualan } \\
\text { hasil tangkapan }\end{array}$ & $\begin{array}{l}\text { 1. Membangun integrasi antara } \\
\text { pemerintah negeri dengan keluarga } \\
\text { nelayan pancing tonda untuk lebih } \\
\text { diperhatikan keberadaanya } \\
\text { 2.Memberikan edukasi tentang } \\
\text { pentingnya suatu kawasan perairan } \\
\text { yang dimanfaatkan secara } \\
\text { tertanggung jawab } \\
\text { 3.Penetapan peraturan negeri tentang } \\
\text { aktivitas pemanfaatan sumberdaya } \\
\text { perikanan secara berkelanjutan } \\
\text { 4.Penentuan harga jual hasil } \\
\text { tangkapan yang disepakati bersama } \\
\text { oleh pihak pengumpul dan nelayan } \\
\text { dan tidak merugikan kedua belah } \\
\text { pihak }\end{array}$ \\
\hline
\end{tabular}

\section{Kekuatan (S)}

1.Ada potensi sumberdaya pesisir dan laut

2.Ada sumberdaya manusia

3.Pengetahuan tentang sumberdaya perikanan yang berekonomis tinggi

4.Mampu mengatur keuangan keluarga

5.Laki-laki dan perempuan berupaya bersama memenuhi kebutuhan ekonomi keluarga
Ancaman (T)

\section{Berkurangnya waktu suami} dan isteri untuk mendidik dan membimbing anak di rumah

2.Minimnya perhatian pemerintah negeri terhadap upaya pemberdayaan isteri nelayan

3.Sumberdaya perikanan berkurang

\section{Strategi (ST)}

1. Pengoptimalisasi pembagian kerja antara suami dan isteri dengan lebih mengefektifkan peran suami dan isteri dalam membimbing anak di rumah.

2. Peningkatan upaya pemberdayaan perempuan pesisir

3. Penetapan peraturan negeri tentang aktivitas pemanfaatan sumberdaya perikanan secara berkelanjutan

\section{Kelemahan (W)}

1.Kaum perempuan belum dilibatkan dalam sistem pemerintahan negeri

2.Minimnya pemahaman nelayan tentang pemanfaatan sumberdaya perikanan yang berkelanjutan
Ancaman (T)

\begin{tabular}{|c|c|}
\hline $\begin{array}{l}\text { 1. Berkurangnya waktu suami } \\
\text { dan isteri untuk mendidik } \\
\text { dan membimbing anak di } \\
\text { rumah }\end{array}$ & $\begin{array}{l}\text { 1. Setiap nelayan memperoleh peluang } \\
\text { untuk ikut serta dalam berbagai } \\
\text { kegiatan maupun pelatihan-pelatihan } \\
\text { dibidang perikanan }\end{array}$ \\
\hline 2.Minimnya perhatian & 2.Membentuk wadah untuk kaum \\
\hline
\end{tabular}




\begin{tabular}{|c|c|c|}
\hline $\begin{array}{l}\text { 3.Hubungan sosial mempengaruhi } \\
\text { nilai jual hasil tangkapan } \\
\text { 4.Kurangnya kegiatan pelatihan } \\
\text { terhadap kaum perempuan pesisir } \\
\text { untuk mengembangan diri } \\
\text { 5.Kelompok perikanan tidak bertahan } \\
\text { lama } \\
\text { 6.Belum ada sistem pengelolaan } \\
\text { perikanan yang berkelanjutan }\end{array}$ & $\begin{array}{l}\text { pemerintah negeri terhadap } \\
\text { upaya pemberdayaan isteri } \\
\text { nelayan } \\
\text { 3. Sumberdaya perikanan } \\
\text { berkurang }\end{array}$ & $\begin{array}{l}\text { perempuan pesisir dapat } \\
\text { mengembangkan potensi diri serta } \\
\text { terwakilkan apsirasinya dalam } \\
\text { pemerintahan negeri } \\
\text { 3. Mengikutsertakan kaum perempuan } \\
\text { pesisir dalam pelatihan-pelatihan } \\
\text { pengembangan diri dibidang } \\
\text { kewirausahaan }\end{array}$ \\
\hline
\end{tabular}

\section{Strategi Integrasi Jender}

Berdasarkan hasil analisis SWOT maka strategi integrasi jender dalam rumah tangga nelayan pancing tonda yang didalamnya memuat aspek eksternal maupaun internal adalah sebagai berikut:

Strategi 1. Penguatan sumberdaya manusia dalam pemanfaatan dan pengelolaan sumberdaya perikanan. Arahan yang dapat diusulkan adalah menghadirkan tenaga-tenaga ahli perikanan untuk melakukan sosialisasi pembatan produk baru dalam pengelolaan sumberdaya perikanan.

Strategi 2. Membangun integrasi antara pemerintah negeri dengan keluarga nelayan pancing tonda untuk lebih diperhatikan keberadaanya. Arahan yang dapat diusulkan adalah sebagai berikut:

1. Mendirikan wadah organisasi nelayan dalam pemerintahan negeri untuk menampung aspirasi nelayan

2. Menambah jumlah perwakilan nelayan paling sedikit 3 orang dalam staf pemerintahan.

Strategi 3. Memberikan edukasi tentang pentingnya suatu kawasan perairan yang dimanfaatkan secara tertanggung jawab. Arahan yang dapat diusulkan adalah sebagai berikut:

1. Melaksanakan pelatihan terhadap masyarakat nelayan tentang aktivitas pemanfaatan beserta dampaknya terhadap sumberdaya dan perairan.

2. Menyelenggarakan diskusi terbuka dengan masyarakat dalam mengkampanye pentingnya suatu kawasan perairan yang bersih bagi kelestarian sumberdaya perikanan dan kesehatan masyarakat.

3. Menggalakan aksi bersih pantai dengan mengikutsertakan seluruh lapisan masyarakat.
Strategi 4. Penetapan peraturan negeri tentang aktivitas pemanfaatan sumberdaya perikanan secara berkelanjutan. Arahan yang dapat diusulkan adalah membuat peraturan tertulis yang melibatkan perangkat negeri, tokoh adat, tokoh agama dan tokoh masyarakat tentang aktivitas perikanan dan perlindungan kawasan pesisir dan perairan negeri.

Strategi 5. Penentuan harga jual hasil tangkapan yang disepakati bersama oleh pihak pengumpul dan nelayan, dan tidak merugikan kedua belah pihak. Arahan yang dapat diusulkan adalah penetapan kisaran harga jual hasil tangkapan yang rasional dan harga jual hasil tangkapan harus disesuaikan dengan kualitas hasil tangkapan.

Strategi 6. Pengoptimalisasi pembagian kerja antara suami dan isteri dengan lebih mengefektifkan peran suami dan isteri dalam membimbing anak di rumah. Arahan yang dapat diusulkan adalah sebagai berikut:

1. Menumbuhkan kesadaran suami dan isteri ntuk tidak hanya berupaya dalam pemenuhan kebutuhan ekonomi keluarga, tetapi juga memperhatikan aspek sosial antar anggota keluarga termasuk didalamnya memperhatikan tumbuh kembang anak dan perkembangan pendidikan anak di rumah.

2. Membuat pembagian waktu antara suami dan isteri untuk menyediakan waktu mengurus anak di rumah.

Strategi 7. Peningkatan upaya pemberdayaan perempuan pesisir. Arahan yang dapat diusulkan adalah sebagai berikut:

1. Perlu adanya pendataan isteri nelayan beserta jenis pekerjaanya selain aktivitas mengurus rumah tangga.

2. Membuat pelatihan-pelatihan terkait usaha perikanan untuk kaum perempuan pesisir. 
3. Membuat kelompok-kelompok usaha yang melibatkan isteri nelayan.

Strategi 8. Setiap nelayan memperoleh peluang untuk ikut serta dalam berbagai kegiatan maupun pelatihan-pelatihan dibidang perikanan. Arahan yang dapat diusulkan adalah sebagai berikut:

1. Pendataan nelayan-nelayan yang sudah ataupun belum pernah mengikuti kegiatan sosialisasi dibidang perikanan.

2. Mengikutsertakan nelayan dalam pelatihan yang sesuai dengan aktivitas perikanan yang sedang ditekuni.

Strategi 9. Membentuk wadah untuk kaum perempuan pesisir dapat mengembangkan potensi diri serta terwakilkan apsirasinya dalam pemerintahan negeri. Arahan yang dapat diusulkan memberikan kesempatan kepada salah satu perwakilan kaum perempuan pesisir untuk menjadi anggota dalam badan pemerintahan negeri.

Strategi 10. Mengikutsertakan kaum perempuan pesisir dalam pelatihan-pelatihan pengembangan diri dibidang kewirausahaan. Arahan yang dapat diusulkan adalah mengadakan pelatihan-pelatihan dibidang kewirausahaan untuk kaum perempuan pesisir dengan memanfaatkan sumberdaya alam setempat.

\section{Analisis Prioritas Aktivitas oleh Laki-laki dan Perempuan dalam Rumah Tangga Nelayan Pancing Tonda.}

Hasil analisis data Analyctical Hierarkhy Process (AHP) terhadap pembagian kerja antara laki-laki dan perempuan dalam rumah tangga nelayan pancing tonda dilihat pada prioritas aktivitas yang dikerjakan oleh laki-laki, perempuan dan antara laki-laki dan perempuan.

\section{Aktivitas oleh laki-laki (AOL)}

Berbagai aktivitas yang dipilih untuk menjadi prioritas terdiri dari aktivitas melaut (M), mengurus rumah tangga (MRT), mengikuti kegiatan sosial (MKS) dan bertani (B), ditampilkan pada Gambar 6.

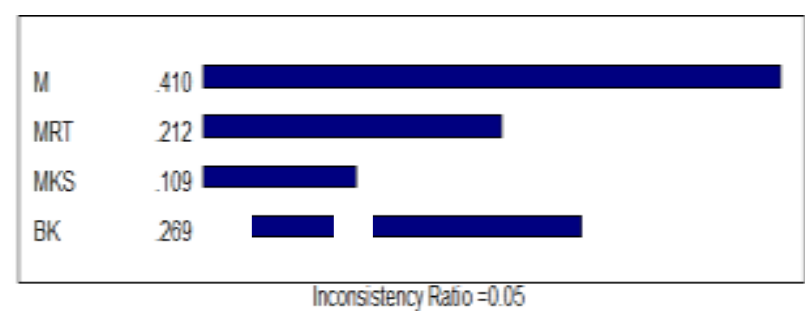

Gambar 6. Hasil analisis aktivitas oleh Lakilaki (AOL)

\section{Aktivitas Oleh Perempuan (AOP)}

Berbagai aktivitas yang dipilih untuk menjadi prioritas terdiri dari aktivitas mengurus rmah tangga (MRT), bertani (B), mengikuti aktivitas sosial lainnya (MASL), berwirausaha (BWS) dan menjual hasil tangkapan (MHT) ditampilkan pada Gambar 7.



Gambar 7. Hasil analisis aktivitas oleh perempuan (AOP)

\section{Aktivitas oleh Laki-laki dan Perempuan (AOLP)}

Berbagai aktivitas yang dipilih untuk menjadi prioritas dalam pembagian kerja antara laki-laki dan prempuan dalam keluarga responden terdiri dari aktivitas laki-laki pergi melaut (LPM), laki-laki pergi bertani (LPB), perempuan mengurus rumah tangga (PMRT), perempuan berwirausaha $(\mathrm{PB})$, perempuan pergi bertani (PPB), perempuan mengikuti aktivitas sosial lainnya (PMASL) dan perempuan menjual hasil kebun (PMHK) ditampilkan pada Gambar 8. 


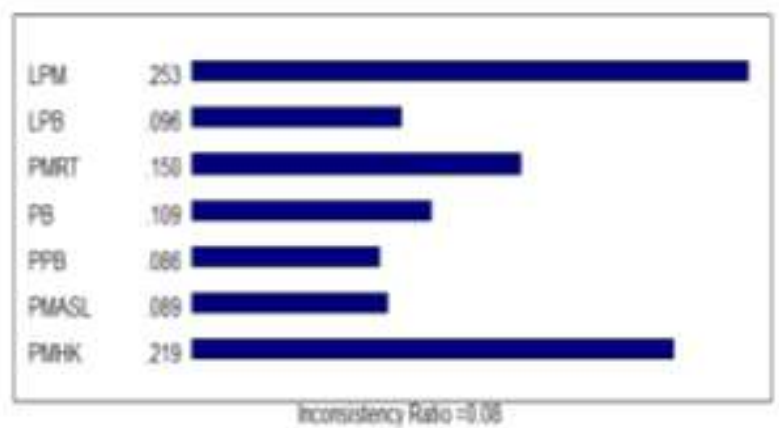

Gambar 8. Hasil analisis pembagian aktivitas oleh laki-laki dan perempuan (AOLP)

\section{KESIMPULAN DAN SARAN}

Berdasarkan hasil penelitian maka dapat disimpulkan sebagai berikut:

1. Aktivitas kaum laki-laki adalah melaut sedangkan kaum perempuan lebih banyak untuk mengurus rumah tangga dan menekuni pekerjaan tambahan lainnya untuk membantu perekonomian keluarga.

2. Aktivitas harian serta pemenuhan tanggung jawab menunjukkan ketidakadilan jender, sehingga menyebabkan terbatasnya ruang lingkup untuk peningkatan kapasitas maupun kehidupan bersosial untuk kaum perempuan.

3. Pembagian kerja antara laki-laki dan perempuan memiliki prioritas yang berbeda, tetapi beban kerja terbanyak di tanggung oleh kaum perempuan.

4. Terdapat 10 strategi dan dirumuskan dalam 17 arahan yang memberikan peran jender baik lak-laki maupun perempuan untuk dapat mengembangkan diri dengan mengacu pada penguatan aspek sosial dan ekonomi.

\section{Saran}

Adapun saran yang dapat disampaikan berdasarkan hasil penelitian yang diperoleh yaitu sebagai berikut:

1. Perlu adanya pendataan ulang oleh pemerintah masing-masing negeri terhadap jumlah nelayan berdasarkan jenis alat tangkap yang dioperasikan.
2. Perlu adanya penelitian lanjutan terkait dengan kondisi taraf hidup keluarga nelayan pancing tonda.

\section{DAFTAR PUSTAKA}

Andriati, R. 2010. Relasi Kekuasaan Suami dan Isteri Pada Masyarakat Nelayan. Jurnal Masyarakat Kebudayaan dan Politik 1(1): 5058.

Azizi, A., Hikmah, S. A. Pranowo. 2012. Peran Gender dalam Pengambilan Keputusan Rumahtangga Nelayan di Kota Semarang Utara, Provinsi Jawa Tengah. Jurnal Sosek KP 7(1): 113-125.

Dinas Kelautan dan Perikanan Kabupaten Maluku Tengah. 2015. Laporan Tahunan Statistik Perikanan. Provinsi Maluku.

Handajani, H., R. Relawati, E. Handayanto. 2015. Peran Gender Dalam Keluarga Nelayan Tradisional dan Implikasinya Pada Model Pemberdayaan Perempuan di Kawasan Pesisir Malang Selatan. Jurnal Perempuan dan Anak 1(1): 1-21.

Hutapea, R. Y. F., A. Kohar, A. Rosyid. 2012. Peranan Wanita Nelayan (Istri Nelayan) Jaring Insang Dalam Meningkatkan Pendapatan Keluarga di Desa Bejalen, Perairan Rawa Pening, Kecamatan Ambarawa, Kabupaten Semarang. Jurnal of Fisheries Utilization Management and Technology 1(1): 1-10.

Kruijssen, F., C. L. McDougall, I.J.M. van Assldonk. 2018. Gender and Aquaculture Value Chains: A Review of Key Issue Implications for Research. Aquaculture 493: 328-337.

Kusumo, R.A.B., A. Charina, G.W. Mukti. 2013. Analisis Gender dalam Kehidupan Keluarga Nelayan di Kecamatan Pangandaran Kabupaten Ciamis. Jurnal Social Economic of Agriculture 2(1): 42-53.

Masitho B D, P. Lestari, M. H. Susanti. 2013. Kehidupan Sosial Ekonomi Perempuan Dalam Masyarakat Nelayan di Desa Panjang Baru Kecamata Pekalongan Utara. Unnes Civic Education Journal 2(2): 33-37.

Rangkuti, F. 2001. Analisis SWOT, Teknik Membedah Kasus Bisnis. Reorientasi Konsep Perencanaan Strategis Untuk Menghadapi Abad 21. PT Gramedia Pustaka Utama. Jakarta. 
Saaty, T. L. 1993. Pengambilan Keputusan Bagi Para Pemimpin, Proses Hirarki Analitik Untuk Pengambilan Keputusan dalam Situasi yang Kompleks. Pustaka Binaman Pressindo. Jakarta.

Singarimbun, M dan S. Effendi. 2008. Metode Penelitian Survei. Jakarta: LP3ES.

Sugiyono. 2008. Metode Penelitian Kuantitatif, Kualitatif dan $R \& D$. Bandung Alfabeta.
UNESCO, 2002. Gender Equality in Basic Education. United Nations Educational, Scientific and Cultural Organization.

Watung, N, C. Dien, O. Kotambunan. 2013. Karakteristik Sosial Ekonomi Masyarakat Nelayan di Desa Lopana Kecamatan Amurang Timur Provinsi Sulawesi Utara. Jurnal Akulturasi 1 (2): 9-12. 